\title{
Assessment of the Design of an Experimental Cover with Capillary Barrier Effect Using 4 Years of Field Data
}

\author{
Amir M. Abdolahzadeh • Benoit Lacroix Vachon • Alexandre R. Cabral
}

A. M. Abdolahzadeh B. Lacroix Vachon A. R. Cabral (\&) Department of Civil Engineering, Faculty of Engineering, Universite' de Sherbrooke, 2500, Boul. de I'Universite', Sherbrooke, QC J1K 2R1, Canada e-mail: Alexandre.Cabral@USherbrooke.ca A. M. Abdolahzadeh e-mail: Amir.abdolahzadeh@usherbrooke.ca

B. Lacroix Vachon e-mail:

Benoit.Lacroix.Vachon@USherbrooke.ca

Geotechnical and Geological Engineering 29 (5): 783-802. DOI 10.1007/s10706-011-9417-x

\begin{abstract}
One important step in the design of inclined covers with capillary barrier effect (CCBE) is the determination of the water diversion length (DL). Numerical simulations can predict the DL more precisely than steady-state analytical solutions. Nevertheless, as simplified methods have always been part of engineering design, the application of analytical solutions with conservative boundary conditions, may allow engineers to make reasonable predictions, particularly during the pre-feasibility stage of a project. In this study, a CCBE was designed, constructed and instrumented at the Saint-Tite-desCaps landfill, Quebec, Canada. This CCBE included a seepage control layer superimposing a sand-gravel capillary barrier. The seepage control layer was made up of deinking by-products (DBP), an industrial byproduct that was previously disposed of as waste. The capillary barrier was designed using an adaptation of the Ross analytical solution and the scenario considered was that of steady-state flow during constant seepage flow applied uniformly at the top of the sandgravel capillary barrier. Although these conditions appear simplistic, they were deemed reasonable because placement of the seepage control layer on the top of the capillary barrier led to very low suctions at the interface, thereby allowing uniform downward seepage rates, limited by the saturated hydraulic conductivity of the DBP. In this paper, a discussion about the behaviour of the cover system based on 4 years of field data from several instruments is presented. The challenge of using DBP, more precisely the settlement of the DBP layer and its impact on ksat, is also assessed. The DL was reassessed considering the new ksat. A discussion on the validity of employing analytical solutions to determine $D L$ is also presented. This paper illustrates how certain variables affect the design of inclined CCBEs that include a highly compressible material as seepage control layer.
\end{abstract}

Keywords: Cover with capillary barrier effect (CCBE) Diversion length Seepage control layer

\section{Introduction}

Covers with capillary barrier effect (CCBE) constitute a valid alternative for minimizing water percolation into the waste mass, hence limiting leachate production in municipal landfill facilities. The capillary barrier effect is formed when a fine-textured soil overlies a coarser one. The textural 
contrast between the upper layer (Moisture Retention Layer, MRL) and the bottom layer (Capillary Break Layer, CBL), helps control water percolation (Hill and Parlang 1972; Ross 1990; Shackelford et al. 1994; Stormont and Anderson 1999; Bussie're et al. 2003; Parent and Cabral 2006; Cabral et al. 2007; Aubertin et al. 2009). In the case of inclined covers, the CCBE is designed to drain percolating water down-slope, where it accumulates at the toe of the MRL. However, when the capillary forces in the MRL become low enough (for instance during or following an intense and/or long precipitation event), any additional percolation seeps into the CBL.

The design of CCBE is fairly complex due to its transient behaviour, and several authors (e.g. Yanful et al. 2006; Aubertin et al. 2009) report that numerical simulations may better define the response of CCBE than steady-state analytical solutions. Nevertheless, analytical solutions, often developed based on a steady-state condition with a constant seepage flow rate along the slope, have been proposed. These simplified assumptions may be unrealistic for natural conditions, but use of steadystate conditions combined with conservative boundary conditions allow engineers to make reasonable predictions using simple tools, particularly during the pre-feasibility stage of a project. Thus, when using simplified solutions, special attention should be paid to the selection of boundary conditions and a conservative worst-case scenario approach is advised

In certain cases, the capillary barrier can be constructed using coarse materials, if the latter are widely available near the landfill site. One positive aspect of such a design is that lateral drainage can be very efficient. A negative aspect is that, during intense and/or long periods of rainfall, the capillary barrier effect may be lost at a short distance from the top of the slope. In such cases, the amount of water that percolates and reaches the waste mass may exceed performance criteria, or-minimally-typical equivalence criteria, where applicable. In order to control and regulate the rate of water percolation reaching the capillary barrier system, a seepage control layer may be added on the top of the system. The rate of percolation is an important boundary condition, which is controlled by the saturated hydraulic conductivity (ksat) of the material placed on top of the capillary barrier.

Cabral et al. (2007) proposed the use of deinking by-products (DBP) as a seepage control layer. DBP, which results from the paper recycling process, was traditionally considered as waste. However, recent studies have shown that it can also be used as alternative geotechnical cover material for landfills (e.g. Moo-Young and Zimmie 1996; Burnotte et al. 2000; Kamon et al. 2001), as well as an oxygen barrier for the prevention of acid mine drainage (Cabral et al. 2000, 2004). Since DBP is highly compressible, its void ratio varies considerably with settlement and its hydraulic conductivity decreases accordingly. The challenge with using this type of material as part of a CCBE is, therefore, to predict how its hydraulic properties, mainly the hydraulic conductivity function ( $k-f c t)$, will change, and to incorporate this variability into the design of CCBES.

A procedure to design inclined CCBEs (material selection and determination of layer thicknesses) was proposed by Parent and Cabral (2006). This methodology is based on the Ross (1990) analytical solution which is binary, i.e. assumes that percolation into the CBL occurs at a precise location down-slope. In fact, percolation into the $\mathrm{CBL}$ increases progressively along the MRL/CBL interface. Parent and Cabral (2006) have proposed an empirical equation to quantify seepage flow into the CBL that can be used as a substitute for the Ross (1990) model. Application of this 
methodology corrects the value of the diversion length (DL) obtained using the Ross model. In order to evaluate the reliability of the proposed design procedure in terms of diversion length, a 30-m long inclined CCBE was constructed in 2005, at the Saint-Tite-des-Caps, Quebec, Canada landfill. Partial assessments of the behaviour of this CCBE have been presented by (Cabral et al. 2007; Lacroix Vachon et al. 2007; Abdolahzadeh et al. 2008; Lacroix Vachon 2008; Abdolahzadeh et al. 2011). This study presents a more comprehensive review, including an in-depth analysis of the design of the proposed alternative cover based on 4 years of field monitoring data. The paper discusses how settlement of DBP affected its ksat, thus the maximum seepage flow rate into the capillary barrier. The latter ultimately affects the main design parameter, i.e. the DL. A discussion on the validity of employing analytical solutions to determine the $\mathrm{DL}$ is presented. This type of exercise is potentially useful to practicing engineers.

\section{Background}

\subsection{Basic Principles of Capillary Barriers (CB)}

CCBEs have been used as an alternative to classical final cover designs for landfills and mine reclamation projects (Morel-Seytoux 1995; Stormont 1996; Ka"mpf and Montenegro 1997; von Der Hude and Huppert 1998; Barth and Wohnlich 1999; Ka"mpf et al. 1999; Morris and Stormont 1999; von Der Hude et al. 1999; Khire et al. 2000; Aubertin and Bussiere 2001; Bussie're et al. 2003; Ka"mpf et al. 2003; Wawra and Holfelder 2003; Berger et al. 2005; Aubertin et al. 2006). In the case of mine site reclamation projects, CCBEs are often used as oxygen barriers in order to limit acid mine production (Cabral et al. 2000; Bussie're et al. 2001, 2003; Molson et al. 2008). The effectiveness of CCBEs has been assessed in the laboratory (Bussie're et al. 1997, 1998; Ka"mpf and Montenegro 1997; Stormont and Anderson 1999; Ka"mpf et al. 2003; Tidwell et al. 2003; Yang et al. 2004), in the field (Stormont 1995a; Stormont et al. 1996; Aubertin et al. 1997; Barth and Wohnlich 1999; von Der Hude et al. 1999; Cabral et al. 2007), as well as by numerical simulations (Akindunni et al. 1991; Oldenburg and Pruess 1993; Bussie're et al. 1995, 2003; Ka"mpf and Montenegro 1997; Webb 1997; Morris and Stormont 1999; Khire et al. 2000; Zhan et al. 2001, 2006; Aubertin et al. 2006, 2009; Cifuentes et al. 2006).

A CCBE can be classified as sloping or nonsloping. A non-sloping CCBE can limit precipitation into the underlying coarse-grained soil layer if the fine-grained soil layer has a high water retention capacity and the evapo-transpiration portion of the water balance is high enough; a condition found mainly in dry climates. A sloping CCBE is designed to drain infiltrating water down-slope. Figure 1 shows water movement in a sloping CCBE. If a vertical seepage flow rate is applied uniformly along the top of the capillary barrier system, part of the infiltrating water will be retained in the fine-grained soil layer due to capillary forces, whereas another part will drain laterally and accumulate down-slope. The diversion capacity (Qmax) is the maximum flow that a capillary barrier can divert. At a critical zone at the interface (dotted square in Fig. 1), called a breakthrough zone, capillary forces no longer retain the accumulated water and moisture starts to infiltrate into the coarse-grained soil layer. This transfer of water becomes more accentuated at a distance from the top of the slope called the diversion length (DL) (Ross 1990). The diversion 
capacity and diversion length depend on the k-fct of the materials composing the CBL and the MRL, the layer thicknesses, the seepage flow rate and the slope of the interface.

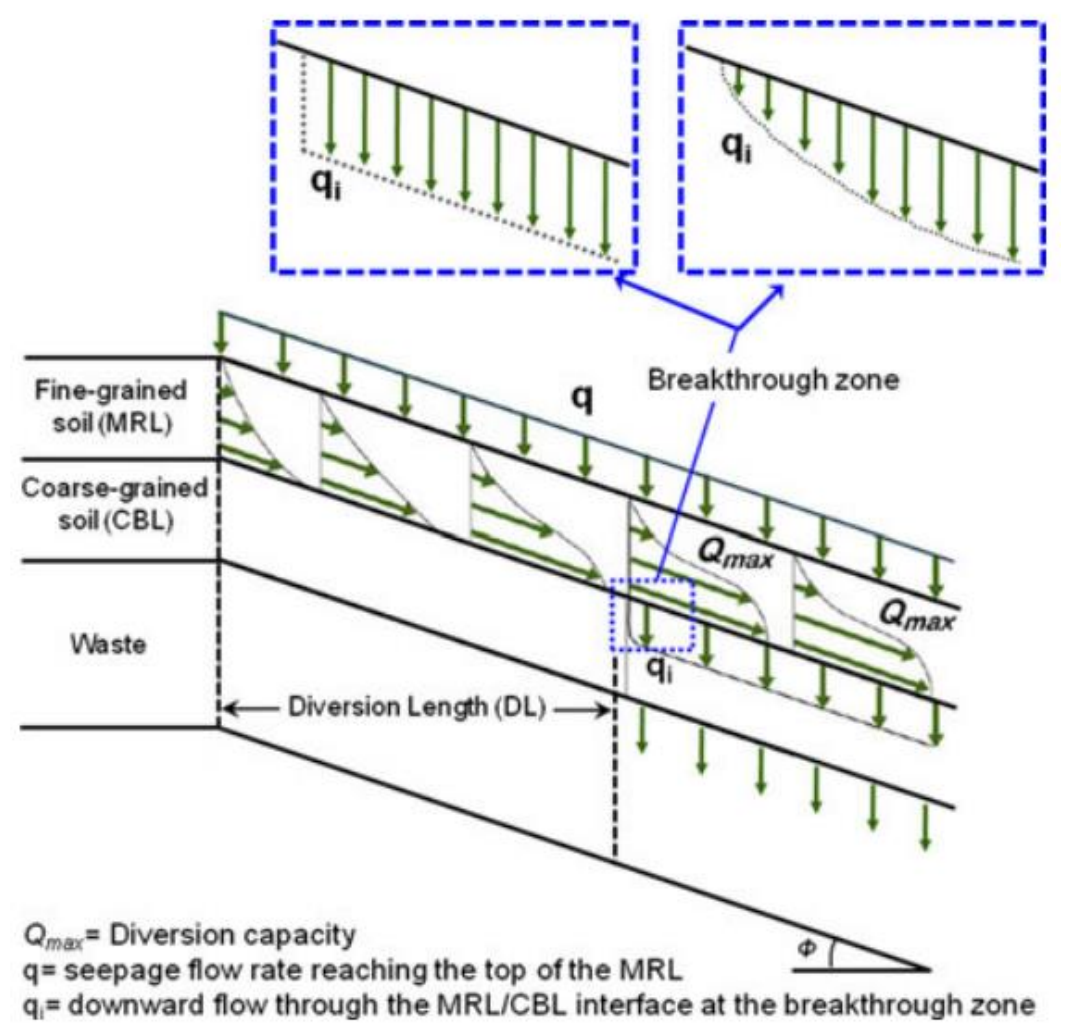

Fig. 1 Schematic of an inclined CCBE. The dotted squares present water flow vectors through the breakthrough zone described by: a the Ross (1990) analytical solution; and b numerical simulations with a progressive downward flow

\subsubsection{Evaluation of the Diversion Length (DL)}

Various equations can be used to evaluate diversion length, such as those proposed by Ross (1990), Steenhuis et al. (1991), Morel-Seytoux (1994), and Stormont (1995b). The Ross model (1990) can be described by Eq. 1:

$$
D L=\frac{Q_{\max }}{q}=\frac{k_{\text {sat }} \tan (\phi) \int_{\psi_{C-C B L}}^{\psi_{C-M R L}} k_{r}(\psi) d \psi}{q}
$$

where the term ksat represents the saturated hydraulic conductivity of the soil $(\mathrm{m} / \mathrm{s}), \mathrm{kr}$ is the relative hydraulic conductivity ( $\mathrm{k} / \mathrm{ksat}), /$ is the slope, $\mathrm{q}$ is the seepage flow rate $(\mathrm{m} / \mathrm{s}), \mathrm{wC}-\mathrm{MRL}$ and $w C-C B L$ respectively are the suction values corresponding to $q$ in the fine-grained and coarsegrained materials $(\mathrm{kPa})$. Figure 2 shows a schematic representation of the lower and upper integral limits of Eq. 1 for two different seepage flow rates (q1 and q2). The lower integration limit ( $W C-C B L$ ) represents a critical suction value, at which the downward flow through the MRL/ CBL interface (qi in Fig. 1) equals the seepage flow rate reaching the top of the capillary barrier ( $q$ in 
Fig. 1). Under this condition, gravity is the driving force (unit gradient) and, as shown in Fig. 2, the value of the unsaturated hydraulic conductivity equals to the seepage flow rate. The upper integration limit is the suction value at the top of the fine-grained soil layer. Under hydrostatic pressure, the upper integration limit is the sum of the critical suction value (lower integration limit-wC-CBL) and the thickness of the fine-grained soil layer. The hypotheses considered for the application of the diversion length calculated according to Eq. 1 are that the upper and lower boundaries of the model must be assumed to be far from each other, the bottom of the slope must be assumed to be well-drained and quite far from the top of the slope and, there is no horizontal flow at the top of the slope.

\subsubsection{Critical Suction Value Through the Capillary Barrier Interface}

According to the Ross (1990) model, water that accumulates at the interface between a fine- and a coarse-grained material layer only starts to flow down when suction reaches a critical value. Steenhuis et al. (1991) suggested that the critical suction value can be considered the water-entry value (WEV) of the coarse material. This suction corresponds to the value at which the downward flow into the coarse material (qi in Fig. 1) becomes equal to the seepage flow rate (q in Fig. 1). Based on the Ross (1990) model, the critical suction value is the suction at which the unsaturated hydraulic conductivity of the CBL becomes equal to the seepage flow rate. This value can be determined graphically (linear method) using the k-fct of the employed materials. As shown in Fig. 2, for a seepage flow rate, q1, the critical suction value of the CBL is wC-CBL-1, whereas for a different seepage flow rate, $q 2$, the latter would be $w C-C B L-2$. Figure 2 also shows that the diversion capacity ( $\mathrm{Qmax}$ ) corresponding to the $\mathrm{q} 1$ (or q2) is the area under the k-fct between the suction of wc-CBL-1 (or wc-CBL-2) and wc-MRL-1 (or wc-MRL-2). It can also be noted in this figure that, for a given combination of materials, the diversion capacity ( $Q$ max) and diversion length (DL) change when the seepage flow rate changes.

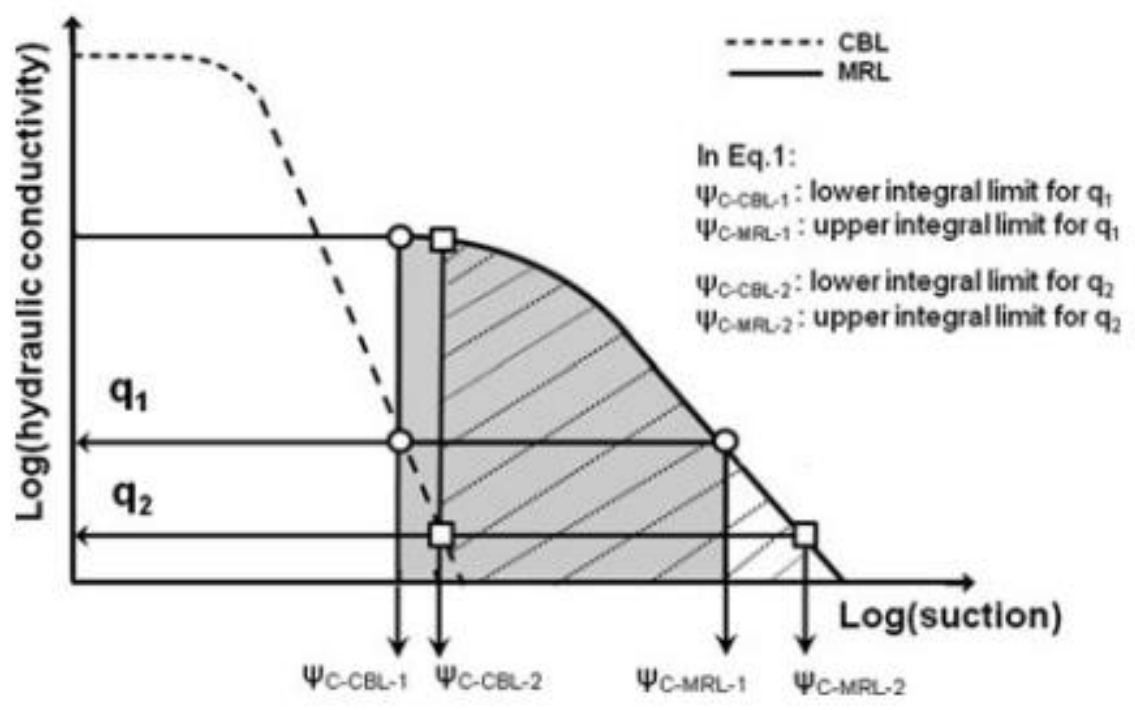

Fig. 2 Schematic representation of the application of the linear method to determine the lower and upper integral limits of Eq. 
According to the Ross (1990) model, before the critical suction value, the fine-grained material drains all the water. Parent and Cabral (2006) performed several steady-state numerical simulations using SEEP/W and showed that the downward flow into the CBL occurs gradually (Fig. 1 , detail within the right-most dotted square), rather than the sudden appearance of qi obtained using Ross (1990) (Fig. 1, detail within the left-most dotted square). Indeed, numerical simulations clearly show that a capillary barrier leaks all along the interface, with downward flow increasing in a sigmoidal manner with distance. As a consequence, attainment of the maximal flow capacity occurs further down-slope than when it is determined using the Ross (1990) model. Considering this, Parent and Cabral (2006) developed a methodology based on the Ross (1990) model, which proposes an empirical equation to quantify seepage flow into the coarse layer, taking into consideration a progressive downward flow into the coarse-grained material. This methodology is based on the fact that the critical suction value can be translated into a seepage flow rate via the k-fct. According to the Ross (1990) model, the critical seepage flow rate is considered to be reached when $100 \%$ of the seepage flow rate crosses the MRL/ CBL interface. Parent and Cabral (2006) proposed a power function that adjusts the Ross (1990) critical downward flow rate at the diversion length point:

$$
q_{i}=0.998 q^{1.024}
$$

where $q$ represents the seepage flow rate reaching the MRL/CBL interface. With the adjusted downward flow rates (qi) obtained using this method, the critical suction values at the interface between the MRL and $C B L$ increase, thus the diversion length increases accordingly.

The procedure proposed by Parent and Cabral (2006) only requires common computer applications such as a spreadsheet and an appropriate compiler. The approach leads to a simple integrated model that is useful particularly in the preliminary phase of the design of CCBEs.

\subsection{Settlement and Hydraulic Conductivity of the DBP}

One particular problem associated with the use of the seepage control layer to control seepage flow rate into a capillary barrier is to determine how its $k$-fct will evolve with time, as settlement occurs. This subject is addressed in this paper and is central to the assessment of the performance of the inclined experimental CCBE installed at the St-Tite-des-Caps landfill. As mentioned earlier, DBP is a highly compressible material whose settlement affects its ksat, which is equivalent to the maximum anticipated seepage flow rate (q) that can reach the top of the MRL. Thus, the evolution of the ksat of DBP due to settlement becomes an important design parameter, because the diversion length is directly influenced by the seepage flow rate. This rate also affects layer thickness optimization and the design of percolation control instrumentation, such as lysimeters.

DBP is a soil-like material in which a fraction of the solid phase is prone to biodegradation and loss of solids due to physiochemical processes. From a mechanical point of view, the behaviour of DBP is somehow similar to that of organic soils. This material is subjected to important settlement, most of which is associated with creep. In general, settlement is described according to Eq. 3:

$$
S=H_{0}\left(\Delta e / 1+e_{0}\right)
$$


where $\mathrm{S}$ represents settlement, $\mathrm{HO}$ is the initial layer thickness, $\mathrm{e} 0$ is the initial void ratio and $\mathrm{De}$ is the change in the void ratio. Settlement is directly related to hydraulic conductivity. The more a material settles, the lower its void ratio is; and, accordingly, the lower its $\mathrm{k}$ is. The relationship between $\mathrm{k}$ and void ratio is given by the $\mathrm{Ck}$ factor (Terzaghi and peck 1967) and can be described by Eq. 4. Robart (1998) reports a value of $\mathrm{Ck}$ between 0.43 and 0.97 for DBP.

$$
C_{k}=\Delta e / \Delta \log k
$$

According to Maltby and Eppstein (1994), during a six-year study, a DBP layer exhibited 33\% settlement. In the laboratory, Quiroz et al. (2000) observed a consolidation of $18 \%$ after 2 years. The results of a laboratory study using large samples, for which a load of $10 \mathrm{kPa}$ was applied, showed that DPB underwent 23-26\% settlement after 56 months (Be'dard 2005).

It is important to be able to predict the settlement of the DBP to assess its long-term effects on ksat. For this purpose, Sowers' (1973) model-a waste soil model-has been applied to fit the settlement data generated in the present study. This model is a widely used approach for prediction of waste settlement, and considers primary and secondary consolidation separately. The Sowers model assumes that the secondary settlement curve is linear with respect to the logarithm of time as expressed in Eq. 5:

$$
S(t)=H\left(t_{c}\right) \cdot C_{\alpha e} \log \left(\frac{t-t_{0}}{t_{1}-t_{0}}\right)
$$

where $\mathrm{S}(\mathrm{t})$ is the secondary settlement $(\mathrm{m}), \mathrm{H}(\mathrm{tc})$ is the height of layer upon completion of primary settlement $(\mathrm{m})$, Cae is the slope of the strain versus log-time curve or the secondary compression ratio, $\mathrm{t}$ is the elapsed time (days), to is the origin of time (days), $\mathrm{t} 1$ is the time for secondary compression to start (days).

\section{Materials and Methods}

\subsection{Design of the Experimental CCBE of the Saint-Tite-des-Caps Landfill Site}

In 2005, an experimental CCBE cover was built at Saint-Tite-des-Caps municipal landfill, Quebec, Canada. The experimental plot was designed using the methodology proposed by Parent and Cabral (2006), which is based on the Ross (1990) analytical solution. The scenario considered in the design procedure was steady-state flow during constant seepage flow applied uniformly at the top of the sand-gravel capillary barrier system. The scenario considered is admittedly simple yet reasonable because of the placement of the seepage control layer (DBP layer) on the top of a capillary barrier (sand-gravel layers), as shown in Fig. 3.

Design variables such as materials, layer thickness as well as slope and length of the cover system were defined in order to obtain a diversion length shorter than the length of the area available to install the experimental plot, i.e. $30 \mathrm{~m}$. The assessment of the DL of this experimental CCBE also required an estimation of the maximum seepage flow rate reaching the capillary barrier (q), which 
in turn required obtainment of the $\mathrm{k}$-fct of DBP. The slope of the cover (5\%) follows the natural slope of the actual cover at St-Tite.

\subsection{Choice of Materials and Layer Thicknesses for the Saint-Tite-des-Caps Landfill Site}

As shown in Fig. 3, the proposed alternative cover included four different layers: (1) a protective layer, which was built using on-site materials; (2) a seepage control layer, built using DBP, which was hauled to the site as part of a larger experimental program aimed at promoting its use as geotechnical material; (3) a Moisture Retaining Layer (MRL), which was chosen between two types of sand found in nearby borrow areas, and; (4) a Capillary Break Layer (CBL), which was selected between two types of gravel also available nearby.

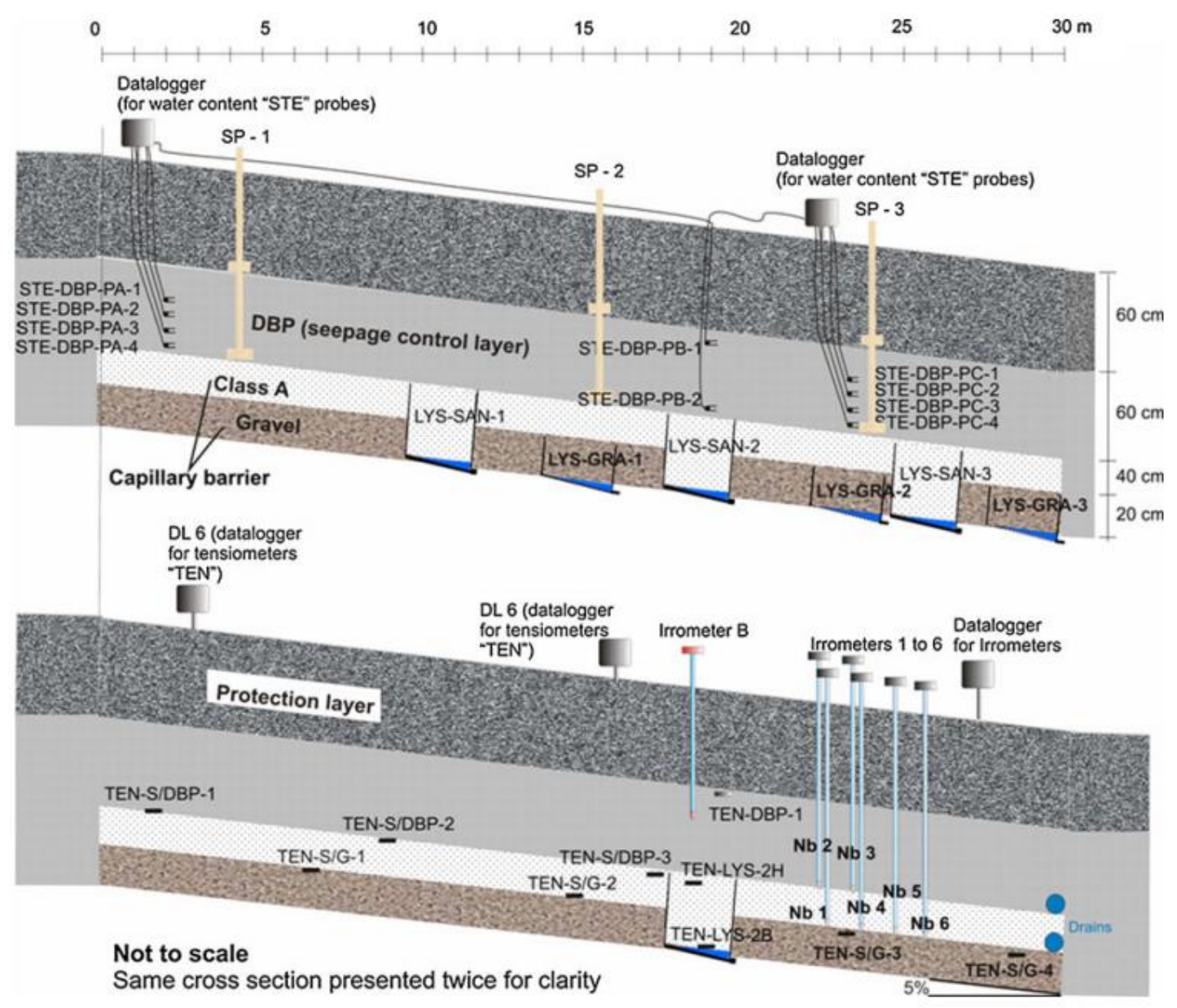

Fig. 3 Profile of the double capillary barrier at the experimental site and some of the instruments installed

\subsubsection{Material Selection}

Demonstration of the effectiveness of the proposed capillary barrier within the present regulatory context in Quebec was possible only if the cover system included the required seepage control layer. According to the Quebec landfilling regulation, REIMR (Gouvernement du Que'bec 2009), the seepage control layer must have a saturated hydraulic conductivity of B1.0 E-7 m/s (1.0E-5 
$\mathrm{cm} / \mathrm{s}$ ) and a minimum thickness of $0.45 \mathrm{~m}$ after compaction. In order to take into account settlement and potential mass loss due to biodegradation (Teixeira 2001; Be'dard 2005; Panarotto et al. 2005; Aı"t-Benichou et al. 2008), a thickness of 0.60-m was adopted for the DBP layer (Cabral et al. 2007). Post-construction monitoring indicated that the actual thickness was $0.63 \mathrm{~m}$.

For the selection of the materials for the MRL and CBL and to optimize layer thicknesses, a representative seepage flow rate (q) was required. The maximum value of $q$ is the ksat of DBP (1.0E-8 m/s, according to Burnotte et al. 2000; Be'dard 2005).

Two types of sand could be used as MRL: a loamy sand and a Class-A sand (numbers 2220 and 1240 on the UNSODA (Leij et al. 1996) database, respectively). The unsaturated properties of these two materials were derived from their particle-size distribution (PSD). Their water retention data were retrofitted using the Fredlund and Xing (1994) functions, while the Mualem (1976) formulation, based on the model proposed by van Genuchten (1980) was used to determine their $\mathrm{k}$-fct (Parent et al. 2006). The saturated hydraulic conductivity and the porosity of the loamy and the Class-A sands were estimated using the neural network in the RETC code (van Genuchten et al. 1991). Once the k-fcts of the two sands were obtained, the linear method (explained previously when describing Fig. 2) was applied to determine the maximal suction value of both types of sand submitted to the design seepage flow rate, $q=1.0 \mathrm{E}-8 \mathrm{~m} / \mathrm{s}$. For the loamy sand, $\mathrm{q}=1.0 \mathrm{E}-8 \mathrm{~m} / \mathrm{s}$ corresponded to a very high suction value $(\& 20 \mathrm{kPa})$, which meant that the material had very limited lateral drainage capacity. Accordingly, the diversion length would be very short. For this seepage flow rate, the suction obtained for the ClassA sand was much lower (\&6 kPa; Fig. 4), indicating that the material would be more effective in draining water laterally, thereby assuring a greater DL. Hence, the Class-A sand was chosen for the MRL (Cabral et al. 2007).

Of the available types of gravel found in a nearby borrow area, the one referred to herein as 'intermediate gravel' (curve shown in Fig. 5) was retained. This material meets the USBR (1974) filter criteria. The lower limit of the PSD of the gravel was determined using two USBR criteria (two points in Fig. 5). These points were fitted by the Fredlund et al. (2000)'s model. The upper limit of the PSD of gravel is the Class-A sand's PSD. 
Fig. 4 Design $k$-fct of the materials selected for the capillary barrier

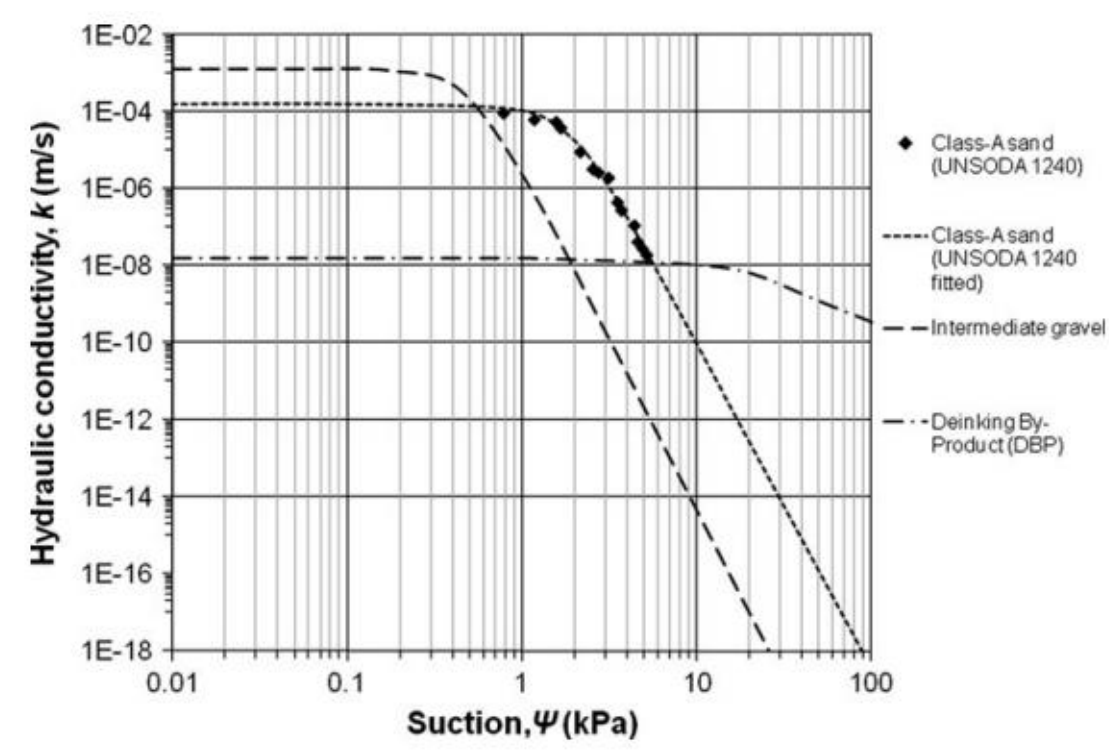

Fig. 5 Particle size distribution $(P S D)$ of the gravel and intermediate gravel

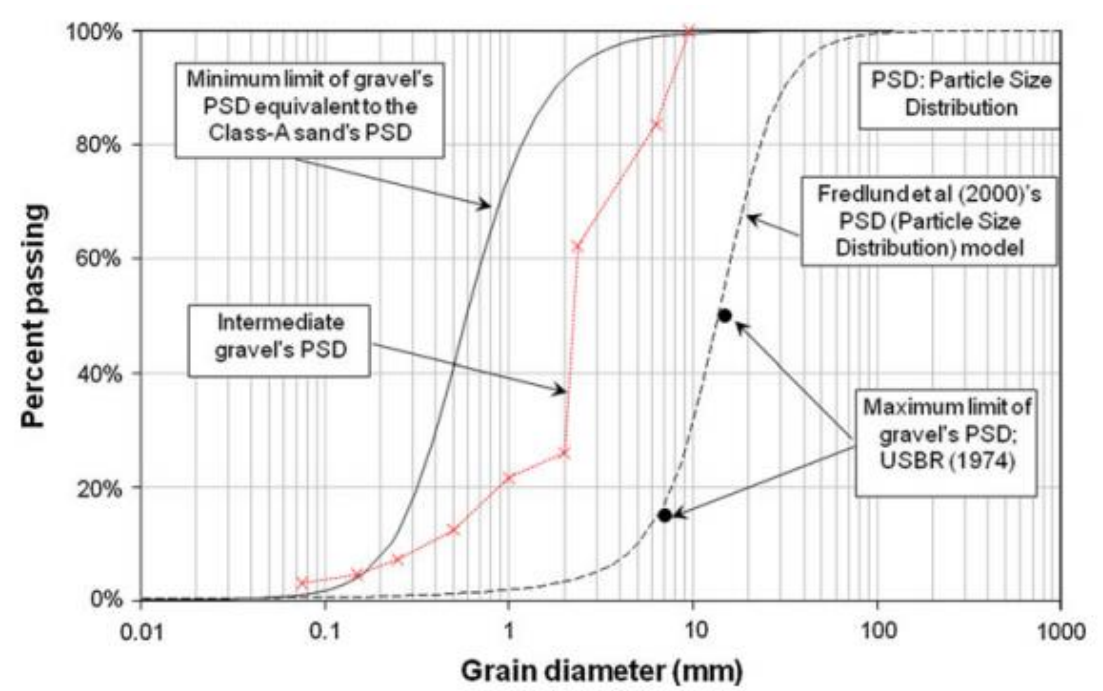

The diversion length of a capillary barrier composed of the two materials selected was evaluated using the Ross (1990) model, which does not require layer thicknesses in the calculations. Under the design seepage flow rate, $q=1.0 \mathrm{E}-8 \mathrm{~m} / \mathrm{s}$, the diversion length obtained was $24.0 \mathrm{~m}$ (Table 2).

\subsubsection{Thicknesses of the MRL and CBL Layers}

The minimal thickness of the intermediate gravel layer corresponds to the height above a water table beyond which suction no longer increases. The Kisch (1959) model was used to calculate the suction profile for a CBL made of intermediate gravel. This analysis led to a CBL thickness of 0.14 $\mathrm{m}$, a value that was adjusted to $0.2 \mathrm{~m}$ (Cabral et al. 2007).

Using SEEP/W, Cabral et al. (2007) performed steady-state numerical simulations to determine the necessary thickness of a MRL made of Class-A sand in order to attain a DL of $\backslash 30.0 \mathrm{~m}$. In these simulations, a 0.2-thick CBL constructed with intermediate gravel, and a steady-state seepage 
flow rate, $q$, equal to $1.0 \mathrm{E} 8 \mathrm{~m} / \mathrm{s}$ were considered. The results showed that a MRL of $0.4 \mathrm{~m}$ was required (Cabral et al. 2007).

\subsection{Experimental CCBE Configuration at the Saint-Tite-des-Caps Landfill Site}

The 30-m-long by 10-m-wide experimental plot, whose profile is presented in Fig. 3, was built in the late summer of 2005 and its performance has been monitored since May 2006. ECH2O EC-5 (Decagon Devices Inc.) water content probes, connected to EM50 (Decagon Devices Inc.) dataloggers, were installed on three profiles to monitor the hydraulic behaviour of the DBP layer (Fig. 3). Prior to installation in the field, the EC-5 probes were calibrated in the laboratory. Sixteen (16) conventional tensiometers (10 UMS Model T4 and 6 Model LT from Irrometer Company) connected to dataloggers (DL6, from Delta-T Devices; and Irrometer RSU for the LT Irrometers) were also installed along the DBP-sand interface and along the sand-gravel interface (Fig. 3) to study the hydraulic behaviour of the CCBE.

Three lysimeters (LYS-GRA-1 to LYS-GRA-3) were installed within the gravel layer, and 3 more (LYSSAB-1 to LYS-SAB-3) were placed within the sand layer (Fig. 3). The bottom of each lysimeter was connected to a pipe that drained (by gravity) the water into a bucket, which was frequently emptied. The lysimeters installed in the sand layer made it possible quantify the seepage flow rate from the DBP layer, whereas those installed in the gravel layer evaluated the net downward flow rate into the waste mass. As explained below, the diversion length of the capillary barrier was also estimated based on lysimetric data.

The height of the lysimeters is of utmost importance and must be evaluated based on expected seepage rates and using the hydraulic conductivity function of the material where it will be placed (Bews et al. 1997). In this study, the lysimeters installed in the gravel layer were 0.2-m high, while those installed in the sand layer were 0.6-m high (as shown in Fig. 3, their bottom is located at the bottom of the gravel layer to accommodate the desired height). The design of the Saint-Tite lysimeters is described in detail by Parent et al. (2006). The lysimeters were built from cylindrical containers having a horizontal surface of $0.85 \mathrm{~m} 2$. They were filled with the same material as the surrounding soil; and the placement densities were the same outside and inside. Three tensiometers were installed to verify the reliability of the lysimeters (further explanation in the Results section). Two drains were installed at the toe of the CCBE to drain percolation away from the DBP and sand layers. Three settlement plates were installed to monitor the mechanical behaviour of DBP. Figure 3 shows three regions of settlement monitoring points, PT-1 positioned up-slope of the cell $(x=4.3 \mathrm{~m})$, PT-2 at mid-length $(x=15.8 \mathrm{~m})$ and PT-3, down-slope $(x=24 \mathrm{~m})$. Each settlement plate was installed at a depth of $0.6 \mathrm{~m}$ from the ground surface. The custommade settlement plates consisted of steel plates attached to metallic pipe rods. The rod connected to the top-most plate is hollow, which permits the bottom-most rod to slide. Settlement can thus be monitored by measuring the elevations of the tops of the rods.

\subsection{Post-Design Characterization of Hydraulic Properties of the Materials Used in the Capillary Barrier}

Further laboratory testing was performed on the Class-A sand, intermediate gravel and DBP samples to reassess their hydraulic properties. Figure 6a presents the WRC of the selected gravel, sand and DBP obtained in the laboratory. More details about the experimental methods can be 
found in Abdolahzadeh et al. (2011). In Fig. 6a, two different curves can be identified for the DBP. The difference between these two laboratory test results is explained later in the paper. Using the WRCs obtained experimentally, the k-fcts were obtained by applying the Mualem (1976) formulation, based on the model proposed by van Genuchten (1980). The k-fcts are presented in Fig. $6 \mathrm{~b}$. The values of the van Genuchten parameters can be found in Table 1.

In the present study, the effect of hysteresis of the WRC was not considered; only the drying curve was used. While it can be important for fine sands, an investigation performed by Maqsoud et al. (2004) showed that for coarse-grained materials, this effect can be considered much less important. Zhang et al. (2009) showed that pore water pressure distributions in modeled capillary barriers, as well as the modeled timing of diversion length (DL) occurrences, are influenced by whether or not hysteresis of WRC is considered.

\section{Results}

This section presents the main results obtained from 4 years of field data. In the first step, the mechanical behaviour of the DBP layer is presented and the saturated hydraulic conductivity (ksat) of DBP is reassessed based on the consolidation data. In the next steps, the reassessment of ksat is conducted in two other ways: using lysimeter and water content data. In the last step, a reassessment of the diversion length is presented.

\subsection{Assessment of the ksat of the Seepage Control Layer Estimated from Settlement Plate Data}

Settlement of the Saint-Tite experimental cover was monitored for nearly 4 years after completion of the cover, in the late summer of 2005. Settlement data for the period up to November 2009 are plotted in Fig. 7. It can be noted that the consolidation rate of the DBP layer starts to level off 3 years after placement. These data also reveal that the short primary consolidation phase occurs during the initial months only, followed by a long phase of creep.

In order to estimate the amount of settlement over time, the settlement plate data were fitted to the Sowers (1973) model (Eq. 5). As shown in Fig. 7, over 4 years, the DBP layer settled $0.12 \mathrm{~m}$, which is equivalent to $20 \%$ of its initial thickness. Of this total, $16.7 \%$ occurred before June 2007 , which means that from June 2007 to November 2009 the ksat, thus the maximum anticipated seepage flow rate $(q)$, remained nearly constant. 

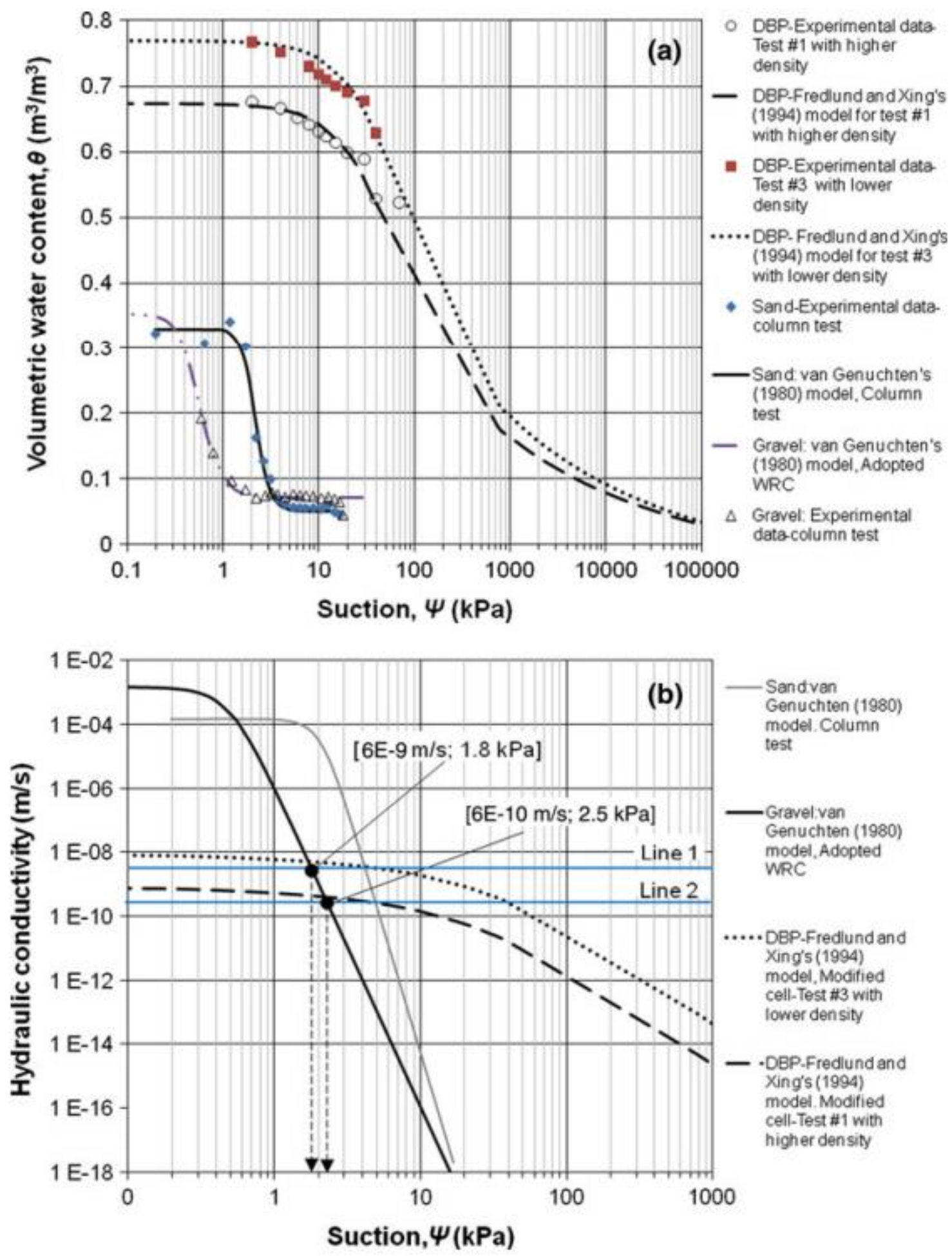

Fig. 6 Post-design characterization. a Water retention curve (WRC); and b k-fct of the materials tested 
Table 1 van Genuchten (1980) parameters for design (Fig. 4) and post-design (Fig. 6) characterization used for determining the DL by analytical solution and numerical modeling

\begin{tabular}{lllll}
\hline$k-f c t$ & Soil & $\alpha\left(\mathrm{kPa}^{-1}\right)$ & $n$ & $k_{\text {sat }}(\mathrm{m} / \mathrm{s})$ \\
\hline Design characterization (Fig. 4) & Class A-sand (estim.) & 0.511 & 3.56 & $1.6 \mathrm{E}-04$ \\
& Intermediate Gravel (estim.) & 2.8 & 4.1 & $2.3 \mathrm{E}-03$ \\
& DBP (pressure plate) & 0.96 & 1.32 & $9.0 \mathrm{E}-08$ \\
Post-design characterization (Fig. 6) & Class A-sand (column) & 0.47 & 6.32 & $1.5 \mathrm{E}-04$ \\
& Intermediate Gravel (column) & 1.95 & 4.20 & $1.5 \mathrm{E}-03$ \\
& DBP (modif. press. plate) & 0.03 & 1.39 & $1.0 \mathrm{E}-09$ \\
\hline
\end{tabular}

$\alpha$ and $n$ are the van Genuchten's (1980) parameters

estim. $=$ estimated

The change in ksat over 4 years was then calculated using Eq. 4 . The initial void ratios of the DBP were determined based on results of sand cone tests performed close to each settlement plate (see insert in Fig. 8). The load associated with the protective layer was approximately $12 \mathrm{kPa}$. Be'dard (2005) performed consolidation tests on DBP samples in the laboratory and obtained aCk value of 0.7 for a loading equal to $12 \mathrm{kPa}$, which is the same value of $\mathrm{Ck}$ obtained in this study (Fig. 8).

Figure 8 illustrates the relationship between hydraulic conductivity and void ratio for DBP. In 2005, the ksat was $1.0 \mathrm{E}-8 \mathrm{~m} / \mathrm{s}$ (obtained in the laboratory). In 2007, this factor decreased by one order of magnitude to reach $1.0 \mathrm{E}-9 \mathrm{~m} / \mathrm{s}$. The change in ksat, caused by physical compression and creep continued in 2008 and 2009. The results for PT-3 differ from the other two, because the area around it had to be reconstructed 2 months after completion of the CCBE due to extreme climatic conditions ( $140 \mathrm{~mm}$ of rain in less than 5 h, i.e. $40 \%$ more than the rain event with a 100 -year return period), coupled with drainage problems at the toe of the experimental cell. Recompaction of this area eventually led to different initial unit weight, thus a different initial void ratio.

\subsection{Assessment of the ksat of the Seepage Control Layer Estimated from Seepage Flow Rates Determined from Lysimetric Data}

Before analyzing the lysimetric data, proper functioning of the lysimeters was evaluated using suction data. According to Bews et al. (1997) the following two conditions must be met to avoid flow bypass. First, the pore water pressure at the base of the zerotension lysimeter must be equal to the atmospheric pressure. Second, the pore pressure at the top of the lysimeter must be equal to the pore pressure just outside of it, at the same elevation. In order to verify if the lysimeters installed met the first condition, a tensiometer (TEN-LYS-2B) was installed at the base of lysimeter LYS-SAN-2 (Fig. 3). To verify the second condition, the evolution of suction values in TEN-LYS-2H and TEN-S/DBP-3 was compared.

As shown in Fig. 9, suction values registered by the tensiometer TEN-LYS-2B in 2006 were approximately equal to zero most of the time, with some occasional positive values indicating that ponding at the bottom occurred for very short periods of time. Figure 9 also shows that, in 2006, suction values recorded for tensiometers TEN-LYS-2H and TEN-S/ DBP-3 were practically equal most of the time, indicating that the lysimeter meets the second condition of design. During certain periods (e.g. early July 2006, May 2008), differences in suction readings were observed. It 
was found that they were related to temporary desaturation of the tensiometers, whose lines were frequently re-saturated.

However, during certain periods in 2007 and 2008, there were considerable divergences in suction readings for TEN-LYS-2H and TEN-S/DBP 3. Abdolahzadeh et al. (2008) suggested two scenarios to explain this difference. In the first, the lysimeter did not work

Fig. 7 Time-dependent nature of the settlements of the DBP layer

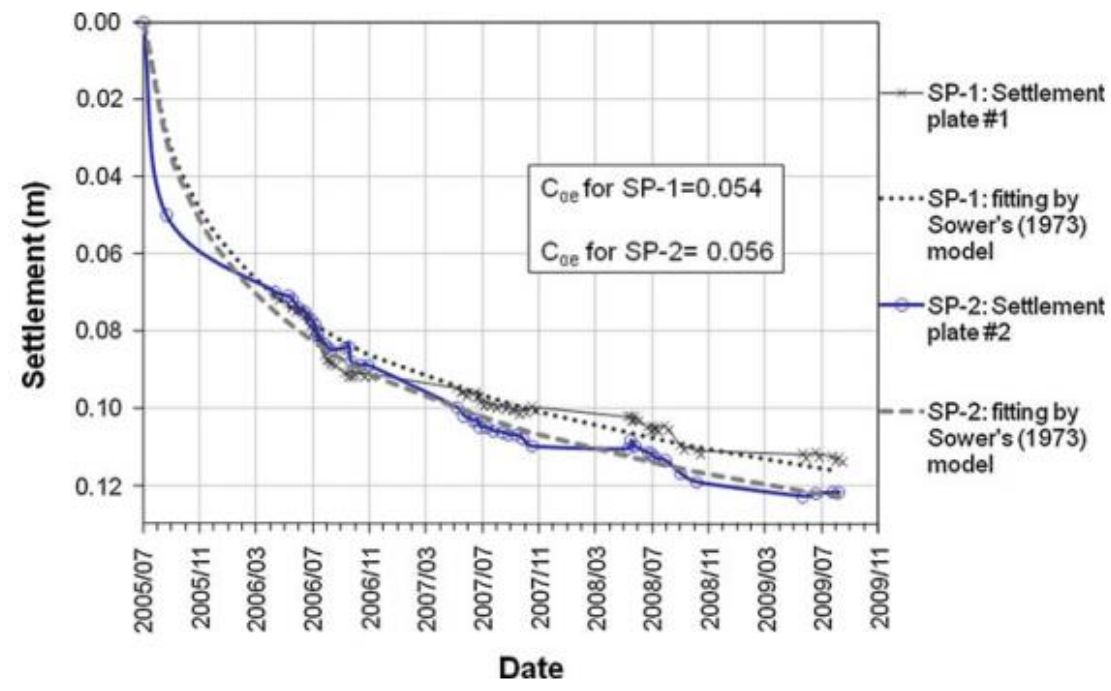

Void ratio

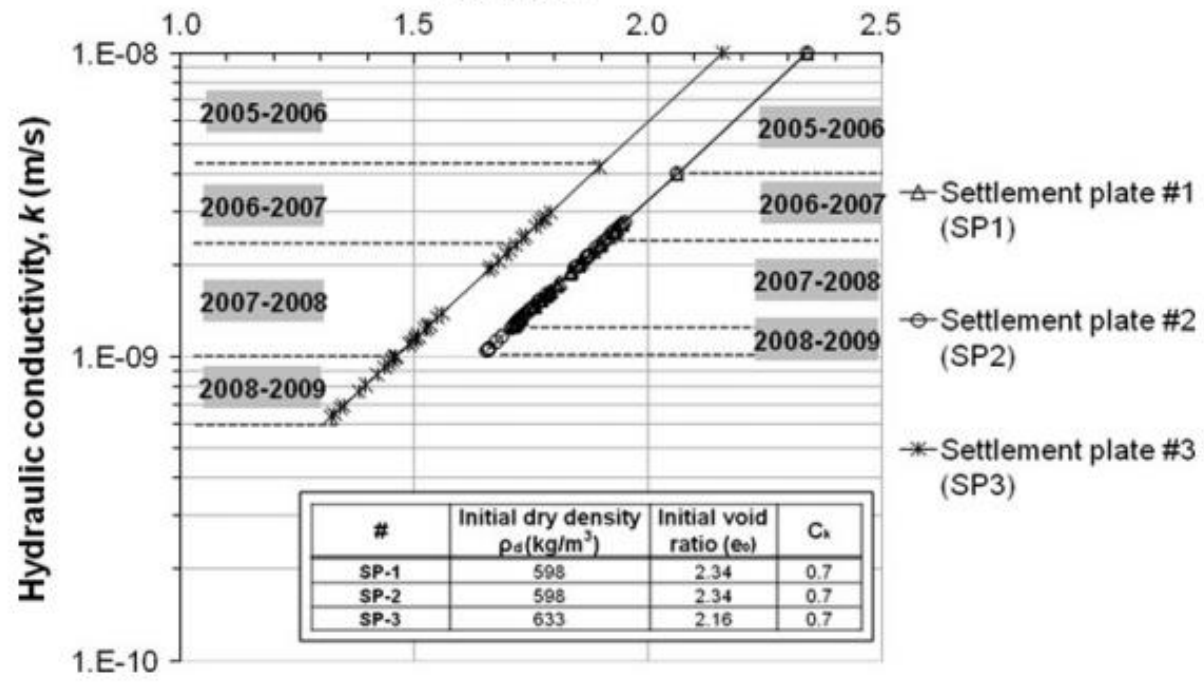

Fig. 8 Relationship between the hydraulic conductivity and void ratio of DBP (data from the last 4 years) 

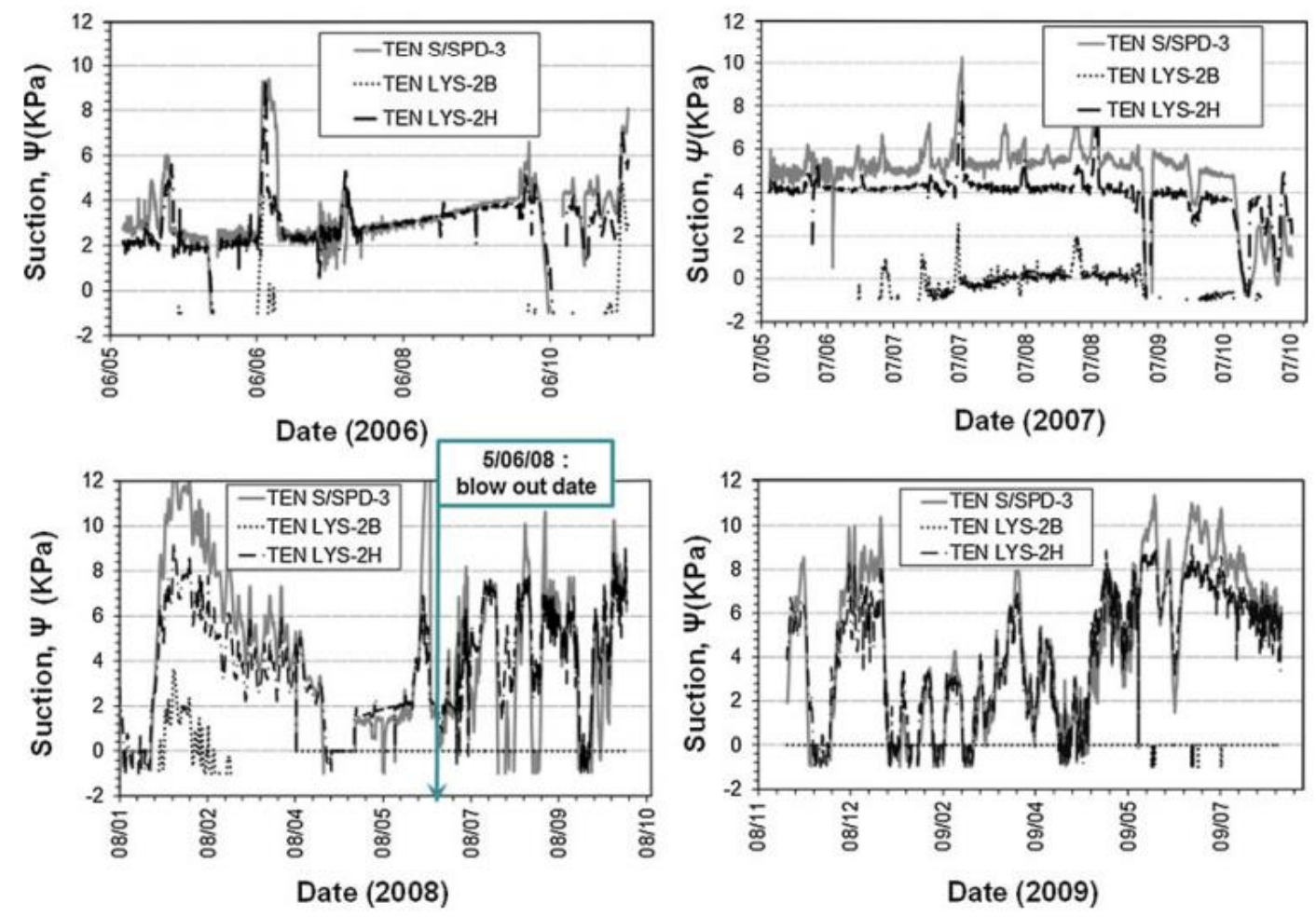

Fig. 9 Evolution over time of suction in tensiometers TEN-S/DBP-3, TEN-LYS-2H and TEN-LYS-2B

as expected due to the decrease in the ksat of DBP, which caused a reduction in anticipated maximum seepage flow rates (q), which, in turn, would lead to greater wall height. In this case, bypass flow would have occurred. The second scenario relates to the possibility of clogging at the exit pipe of the lysimeter. As shown in Fig. 9, positive pore pressures were registered more often in 2007 than in 2006. This would lead to lower suctions at the top center of the lysimeter than outside its rim, causing flow by-pass. In order to verify the second scenario, on June 5, 2008, the drainage pipes of all the lysimeters were blown out using compressed air. It can be observed that after this procedure (indicated in Fig. 9 as "blow out date"), suction values in the two tensiometers were practically equal most of the time, indicating that clogging was indeed impeding efficient drainage.

For further interpretation of lysimetric data, it is possible to use meteorological data from the onsite weather station (Vantage Pro; Davis Instruments), which are presented in Fig. 10. The accumulated precipitation in 2006 was approximately $535 \mathrm{~mm}$, which was the lowest rate in 4 years of monitoring. Accordingly, the quantity of water collected in the lysimeters in 2006 should be less than in each of the 3 following years. However, seepage flow rate data shown in Fig. 10, which were obtained from the amounts of water collected from the 3 lysimeters installed in the sand layer, do not corroborate this assumption. Throughout 2006, the maximum seepage flow rate attained was $1.0 \mathrm{E}-8 \mathrm{~m} / \mathrm{s}$, whereas from 2007 to 2009 the maximum attained was close to $1.0 \mathrm{E}-9 \mathrm{~m} / \mathrm{s}$. Since the maximum seepage flow rate that can reach the sand layer is the ksat of the DBP, this observation helps to confirm the impact of settlement on ksat, thus on maximum seepage flow rate $(q)$. 


\subsection{Assessment of the ksat of the Seepage Control Layer Estimated from Water Retention Curves Obtained Using Field Data}

The in situ WRC of DBP can be obtained using volumetric water content (h) and suction (w) measurements. Frequent measurements of $w$ values were obtained from tensiometers TEN-DBP1 while water content probe STE-DBP-PB-1 provided values of $h$. Figure 11 illustrates the field derived WRCs of DBP. For 2006 and 2007, there were considerable variations in $\mathrm{h}$ for the same $\mathrm{w}$ indicating that a unique curve cannot describe the behaviour of DBP.

In order to re-determine the laboratory WRC with the initial dry density (qd) as close as possible to the field qd, a series of laboratory tests were carried out using a modified pressure plate. The field qd-2006 of DBP was obtained from sand cone tests performed during the construction phase, whereas field qd-2007 was estimated based on settlement plate data.

Figure 11 shows the fitted WRC using the Fredlund and Xing (1994) model for test \#3 and test \#1. For these tests, the samples of DBP were compacted under conditions (density and water content) observed in 2007 and 2006, respectively. The van Genuchten (1980) model was used to fit field data for 2006 and 2007. A clear downward shift of the WRC can be noted between 2006 and 2007, i.e. lower values of $h$ are obtained for the same value of $w$. This results from settlement of the DBP layer. Since the k-fct of DBP was derived from its WRC, it can be expected that lower values of ksat are obtained for the same values of $\mathrm{w}$.

Fig. 10 Evolution of seepage flow rates by lysimeters installed in the sand layer, during 4 years

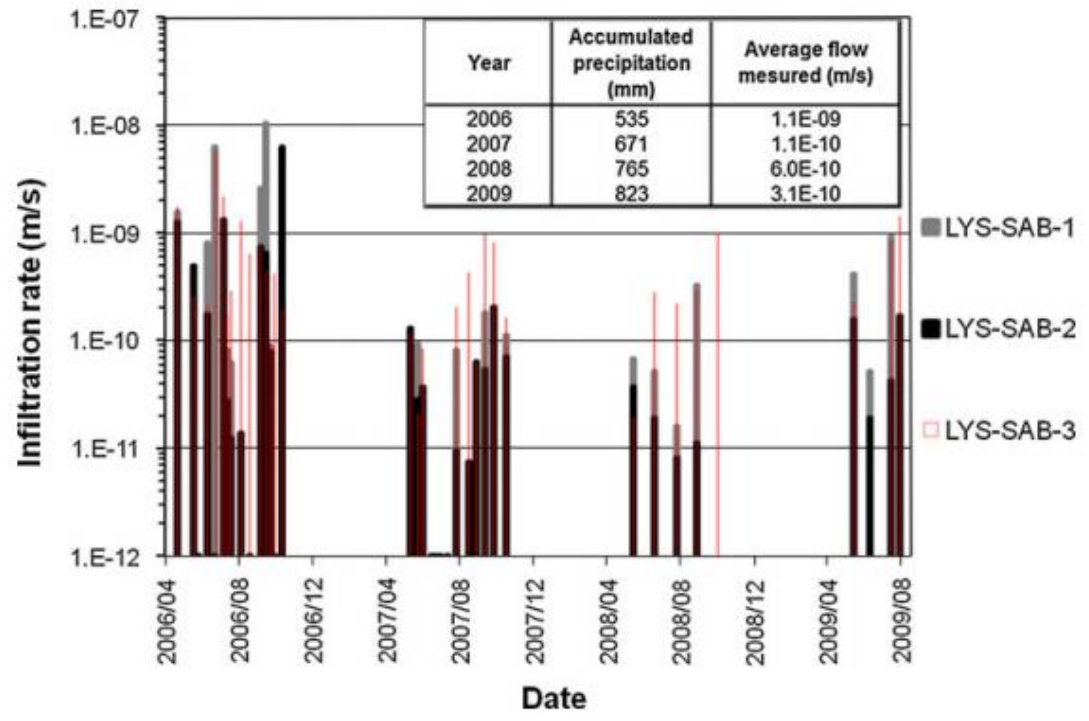


Fig. 11 WRCs determined in the laboratory and from retro-analysis of available water content and suction measurements for 2006 and 2007

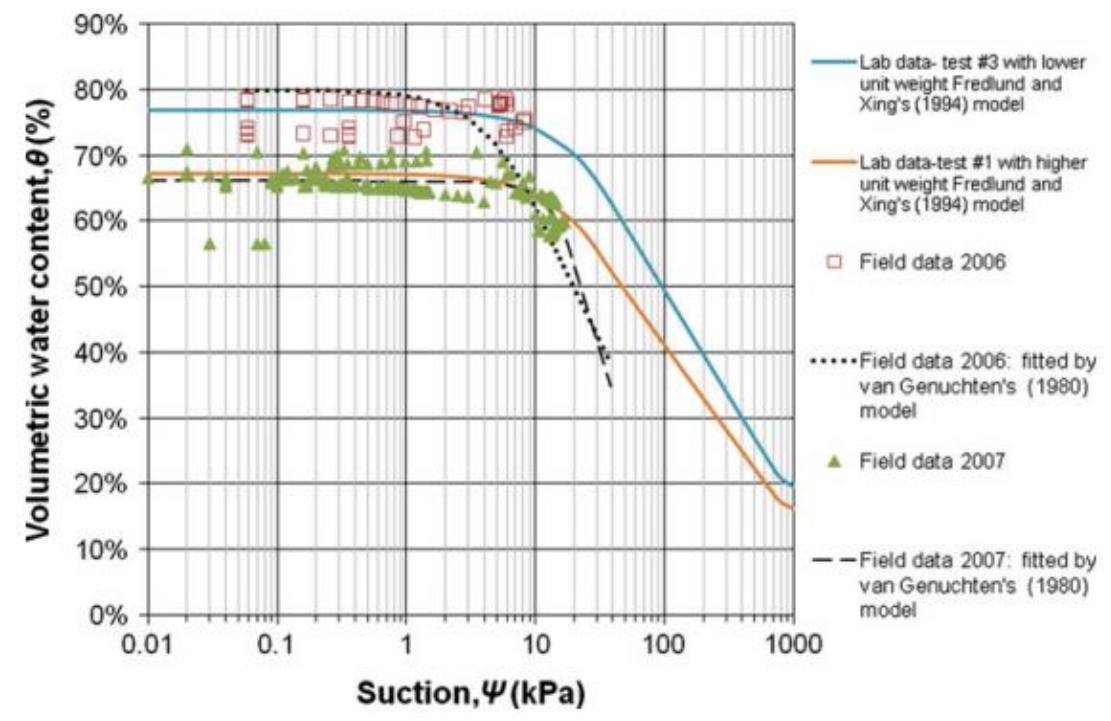

\subsection{Reassessment of the Diversion Length}

As mentioned in the Background section, the critical suction value is the pressure at which the diversion length starts to be attained. The latter can be translated into seepage flow rate using the $\mathrm{k}$-fct. With the adjusted seepage flow rates (qi) obtained using Eq. 2, the critical suction values at the interface between the sand and gravel layer can be determined. They correspond to the point where qi crosses the $\mathrm{k}$-fct for the gravel, as illustrated in Fig. $6 \mathrm{~b}$. In this figure, Line 1 corresponds to the corrected seepage flow rate for 2006 (qi $=6.0 \mathrm{E}-9 \mathrm{~m} / \mathrm{s}$ ), which was obtained by applying Eq. 2, and considering a hydraulic gradient equal to 1 . Line 1 corresponds to a critical suction equal to $1.8 \mathrm{kPa}$. Line 2 corresponds to the corrected seepage flow rate from 2007 to 2009 , i.e. $q i=6.0 \mathrm{E}-10 \mathrm{~m} / \mathrm{s}$ (again, for $\mathrm{i}=1$ ), and the corresponding critical suction value for this period was $2.5 \mathrm{kPa}$. When the suctions at the interface of the sand-gravel capillary barrier reach these critical values, the diversion length can be considered attained.

\subsubsection{Reassessment of the Diversion Length Based on Tensiometric Data}

Data from the four tensiometers placed along the sand/gravel interface (Fig. 3) were analyzed for different periods of intermittent to intense precipitation. The results, presented in Fig. 12, show that suction values decreased towards the toe of the slope, and, in 2006, started to stabilize at a suction value slightly lower than $1.8 \mathrm{kPa}$, at approximately the $23-\mathrm{m}$ mark. The same observation is valid for all periods analyzed for 2006. This indicates that the diversion length was attained near the 23-m mark, i.e. $23 \mathrm{~m}$ away from the top of the slope.

In 2007, 2008 and 2009, following the decrease in ksat of the seepage control layer, the maximum seepage flow rate $(q)$ reaching the sand-gravel capillary barrier changed, causing an increase in the DL. Accordingly, higher suctions were found in the sand layer both up-slope (6-8 kPa) and down-slope ( $* 2.5 \mathrm{kPa}$ ) of the capillary barrier. In Fig. 12, it can be observed that, apart from two sequences in 2007, the suction value in the sand/gravel interface shows no sign of stabilization at the 23-m mark. In 2008, except for the first period (2007/11-2008/01), the suction values decreased up-slope $(7-8 \mathrm{kPa})$ and down-slope $(2.5-4 \mathrm{kPa})$ and-again-there were no signs of stabilization of suction. In 2009, the suction values recorded at the top and bottom of the 
experimental plot were quite similar and varied between 8.0 and $4.5 \mathrm{kPa}$. At the $30-\mathrm{m}$ mark the critical suction, thus the DL, had not been attained. In this case, the DL would be attained beyond the perimeter of the 30-m experimental cell.

\subsubsection{Reassessment of the Diversion Length Based on Steady-State Numerical Simulation, Ross Analytical Solution, and Parent and Cabral Method}

In order to estimate the $\mathrm{DL}$ associated with the new ksat, numerical models were built and simulations were performed using the computer program SEEP/ W. The Ross (1990) analytical solution and the method proposed by Parent and Cabral (2006) were also employed.

Figure 13 shows the increase in DL calculated using the Parent and Cabral (2006) and the Ross (1990) methods using the design (Fig. 4) and postdesign (Fig. 6b) k-fct. The van Genuchten (1980) parameters used in this study are presented in Table 1.

It can be noted in Fig. 13 that the DL increases when the void ratio of DBP decreases and that quite different $D L$ values are found if the post-design $\mathrm{k}$ - $\mathrm{fct}$ is used instead of the design $\mathrm{k}$ - $\mathrm{fct}$. This difference is associated with changes in the values of the van Genuchten parameters, particularly $\mathrm{n}$ (desaturation slope).

pe). For example, for the Class-A sand, the value for the desaturation slope, $n$, obtained during the design phase is equal to 3.56 , whereas the value adopted for post-design is almost the double (6.32; Table 2). As shown in Fig. 13, the lower the seepage flow rate, the greater the impact of van Genuchten (1980) parameters on DL. Consequently, in a particular project where a steadystate analysis is adopted during the feasibility study, the lower the seepage flow rate adopted, the greater the care required in obtaining the unsaturated soil parameters for the materials constituting the capillary barrier.

In order to verify the exactness of the Parent and Cabral (2006) method in determining DL, several steady-state numerical simulations by SEEP/W were performed using design and post-design kfct and two seepage flow rates, i.e. the 2006 ksat and the post 2007 ksat. Table 2 summarizes the main values of DL obtained. The results obtained show that the Parent and Cabral (2006) method compares quite well with those found by steady-state numerical simulation, both in the case of design and post-design k-fct. The Ross (1990) method yielded quite conservative values. 
Fig. 12 Evolution of suction along the sand/ gravel interface for several periods from 2006 to 2009

Fig. 13 Saturated hydraulic conductivity of DBP versus diversion length calculated by different methods using the post-design $k$-fct
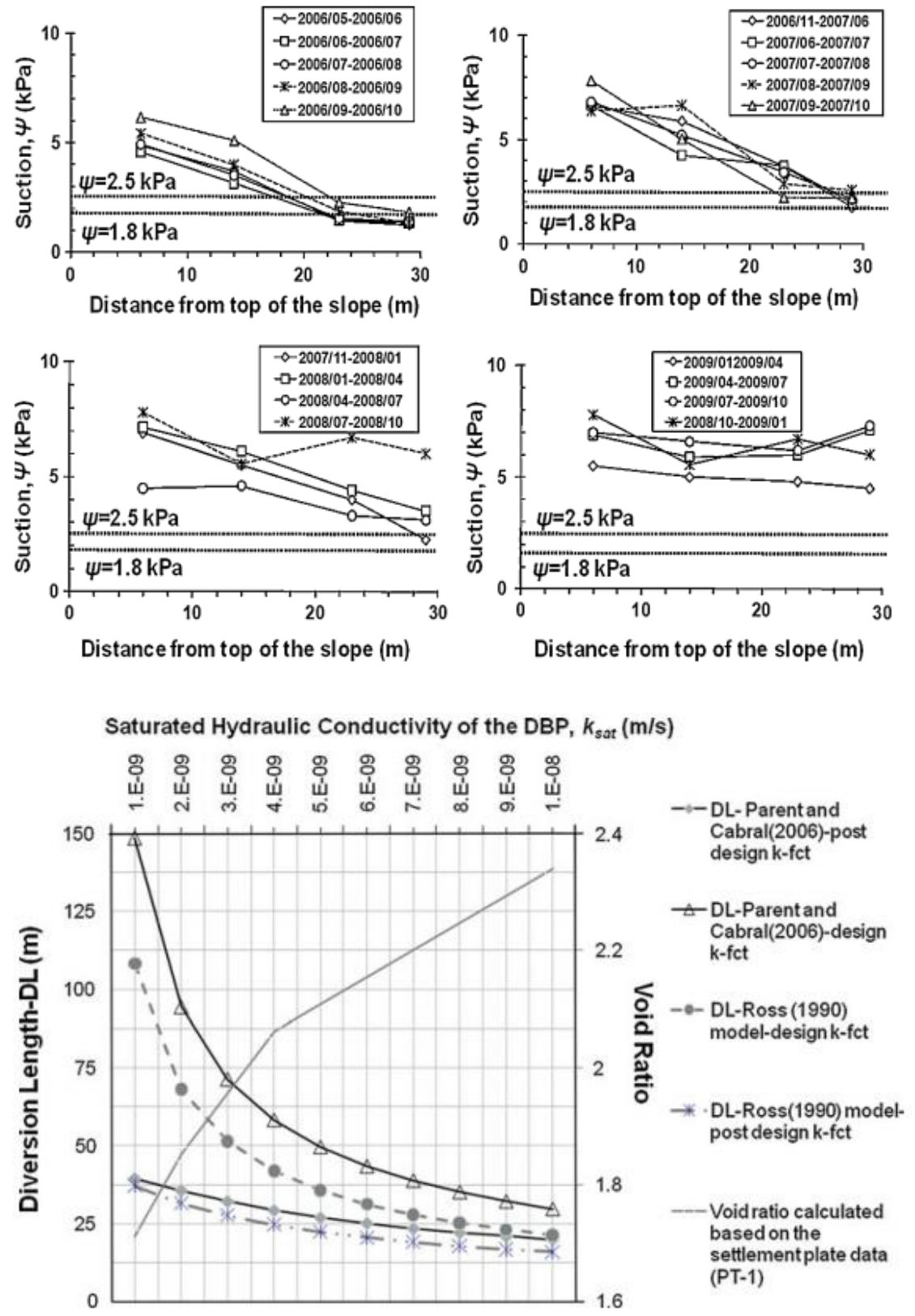
Table 2 Comparison between DL modelled on SEEP/W and theoretical DL calculated by Parent and Cabral (2006) and Ross (1990) model, for different infiltration rates

\begin{tabular}{llll}
\hline $\begin{array}{l}K_{\text {sat }} \text { of DBP }= \\
\begin{array}{l}\text { Maximum flow } \\
\text { reaching the } \\
\text { capillary barrier } \\
\text { system (m/s) }\end{array}\end{array}$ & $\begin{array}{l}\text { Tool used } \\
\text { to evaluate } \\
\text { the diversion } \\
\text { length }\end{array}$ & $\begin{array}{l}\text { Diversion } \\
\text { length } \\
\text { using } \\
\text { design } \\
k-f c t(\mathrm{~m})\end{array}$ & $\begin{array}{l}\text { Diversion } \\
\text { length } \\
\text { using } \\
\text { post- } \\
\text { design } \\
k-f c t(\mathrm{~m})\end{array}$ \\
\hline $1.0 \mathrm{E}-08^{\mathrm{a}}$ & $\begin{array}{l}\text { SEEP/W } \\
\text { Parent et Cabral } \\
(2006)\end{array}$ & 31 & 19 \\
& $\begin{array}{l}\text { Ross (1990) } \\
\text { SEEP/W }\end{array}$ & 29 & 20 \\
$1.0 \mathrm{E}-09$ & $\begin{array}{l}\text { Parent and Cabral } \\
(2006)\end{array}$ & 148 & 16 \\
& Ross (1990) & 108 & 42 \\
\hline
\end{tabular}

a Seepage flow rate retained in the original design

${ }^{\mathrm{b}}$ Design diversion length

It is striking how consideration of the proper k-fct (i.e. proper unsaturated soil parameters) affects the value of $\mathrm{DL}$ : for example, if the design $\mathrm{k}$-fct and a maximum seepage flow rate equal to $1.0 \mathrm{E}-$ $9 \mathrm{~m} / \mathrm{s}$ are considered, DL equals *145 m (SEEP and Parent and Cabral 2006; Table 2), whereas consideration of the post-design $\mathrm{k}$ - $\mathrm{fct}$ gives a DL value of approximately $40 \mathrm{~m}$. This substantiates the need to re-assess unsaturated soil parameters during the design process.

\subsection{Discussion on the Validity of Employing Analytical Solutions to Determine DL}

Inclined CCBEs constitute complex systems that can be influenced by several factors. There are two methods for designing an inclined CCBE, depending on the stage of the project: (1) analytical solutions, such as Ross (1990), Morel-Seytoux (1994), etc.; and (2) numerical modelling. Analytical solutions may constitute a powerful tool in the pre-feasibility stage of a project.

Bussière et al. (2007) discussed existing analytical solutions that are based on a steady-state approach. They pointed out that $\mathrm{DL}$ is a time-dependent variable; as a consequence, proper evaluation of the behaviour of inclined CCBEs requires the use of transient analysis (Bussière et al. 2003; Cifuentes et al. 2006; Yanful et al. 2006; Aubertin et al. 2009). Bussière et al. (2007) also express concerns about the risk of oversimplifying the design of CCBEs by using analytical solutions, which must be employed with great care.

The Authors entirely agree with the above. However, the results obtained in this study indicate that the use of steady-state conditions combined with worst-case scenario boundary conditions may allow practitioners to make reasonable predictions using simple tools during the prefeasibility studies. 
Regardless of the means adopted, unsaturated soil parameters, particularly the k-fct remain a great uncertainty. Errors related to its obtainment may be far greater than errors related to the use of simple analytical methods.

\section{Conclusion}

A 30-m experimental landfill cover with capillary barrier effect (CCBE) was constructed at the SaintTite-des-Caps municipal landfill, Quebec, Canada. The capillary barrier was built using available materials around the experimental site; i.e. a ClassA sand, which acted as the moisture retaining layer (MRL) and an intermediate gravel, which acted as the capillary break layer (CBL). It was nonetheless necessary to install a seepage control layer (DBP layer) over the capillary barrier composed of coarse materials; otherwise the capillary barrier effect would be easily lost as a consequence of intense or long periods of rainfall. In this project, deinking byproducts (DBP), a highly compressible material, were used as a seepage control layer.

The capillary barrier was designed using a methodology described in Parent and Cabral (2006), which is an adaptation of the Ross (1990) analytical solution. The scenario considered was that of steadystate flow during constant seepage flow applied uniformly at the top of the sand-gravel capillary barrier. The scenario is admittedly simple yet reasonable because of the placement of the seepage control layer on the top of a capillary barrier. The value of DL obtained using this methodology was less than $30.0 \mathrm{~m}$.

The $\mathrm{k}_{\text {sat }}$ of the DBP obtained in the beginning of the project was considered in the design of the experimental plot as the maximum seepage flow rate that could reach the sand-gravel capillary barrier. For the 2 years following construction (2006 and 2007), data from tensiometers installed along the sand/ gravel interface indicated that the diversion length was located near the $23 \mathrm{~m}$ mark, where suctions dropped below the critical value, thus the capillary barrier effect was progressively lost. These results indicate that the capillary barrier composed of coarse materials and topped by a seepage control layer was able to drain infiltrating waters away from the waste mass over the desired (and designed) length of cover. They also indicate that the overall design approach based on the use of a steady-state analytical solution may constitute a reliable design tool for inclined CCBEs, if conservative boundary conditions are considered. The Authors acknowledge, however, that use of transient analyses of unsaturated flow constitutes a more powerful design tool.

Despite the fact that the predictions materialized in the first 2 years following construction, evolution of the consolidation of the DBP layer led to a decrease in the ksat of one order of magnitude, from $1.0 \mathrm{E}-08$ to $1.0 \mathrm{E}-09 \mathrm{~m} / \mathrm{s}$. The decrease, which was crosschecked using field data-particularly lysimetric and water content data, meant that the diversion length would be greater than the design value. Indeed, an increase in suction values was recorded for 2008 and 2009 at the tensiometers placed along the sand/gravel interface. This triggered a reassessment of both the $\mathrm{DL}$ and design procedure.

In order to estimate the DL associated with the new ksat, the same design methodology was adopted, i.e. the Parent and Cabral (2006) model, the Ross (1990) method and steady-state numerical simulations. Post-design k-fcts were derived from newly laboratory-determined WRCs for all the materials. The DL obtained using Parent and Cabral (2006) and steady-state numerical 
simulations were 40 and $42 \mathrm{~m}$, respectively, i.e. greater than the total length of the experimental plot.

When designing a CCBE such as the one presented in this study, the engineer may have the opportunity to introduce an economical and environmentally friendly use of a particular type of waste material, namely deinking by-products. However, care must be taken to evaluate the progression of the hydraulic conductivity if the material considered for seepage control layer is compressible. In the present study, the long-term diversion length was under-evaluated.

\section{Acknowledgments}

Funding for this study was provided by Cascades Inc. and the Natural Sciences and Engineering Research Council (NSERC) (Canada) under the Universitylndustry Partnership grant number CRD 192179 and by NSERC under the second Author's Discovery Grant. The authors also acknowledge help provided by Jean-Guy Lemelin in the design of the experimental cell, installation of the measuring system and with actual testing. The third Author completed part of this study while working at the Federal University of Santa Catarina, Brazil, where he was a Visiting Professor with a grant from Coordenac,ão de Aperfeic,oamento de Pessoal de Nı́vel Superior (CAPES)/Brazil. 


\section{References}

Abdolahzadeh AM, Vachon BL, Cabral AR (2008) Hydraulic barrier and its impact on the performance of cover with double capillary barrier effect. In: 61e Conférence géotechnique canadienne, Edmonton, 21-24 Sept

Abdolahzadeh AM, Lacroix Vachon B, Cabral AR (2011) Evaluation of the effectiveness of a cover with capillary barrier effect to control percolation into a waste disposal facility. Can Geotech J (accepted)

Aït-Benichou S, Cabral AR, Panaroto CT (2008) Evolution of biodegradation of deinking by-products used as alternative cover material. Waste Manag 28:85-96

Akindunni FF, Gillham RW, Nicholson RV (1991) Numercial simulations to investigate moisture-retention characteristics in the design of oxygen-limiting covers for reactive mine tailings. Can Geotech J 28:446-451

Aubertin M, Bussiere B (2001) Water flow through cover soils using modeling and experimental methods. J Geotech Geoenviron Eng 127(9):810-811

Aubertin M, Bussière B, Barbera J-M, Chapuis RP, Monzon M, Aachib M (1997) Construction and instrumentation of in situ test plots to evaluate covers built with clean tailings. In: 4th International conference on acid rock drainage, Vancouver, 31 May-6 June. Balkema, pp 717-727

Aubertin M, Cifuentes E, Martin V, Apithy S, Bussiere B, Molson J, Chapuis RP, Maqsoud A (2006) An investigation of factors that influence the water diversion capacity of inclined covers with capillary barrier effects, Carefree, AZ, United States. American Society of Civil Engineers, Reston, pp 613-624

Aubertin M, Cifuentes E, Apithy SA, Bussière B, Molson J, Chapuis RP (2009) Analyses of water diversion along inclined covers with capillary barrier effects. Can Geotech J 46(10):1146-1164

Barth C, Wohnlich S (1999) Proof of effectiveness of a capillary barrier as surface sealing of sanitary landfill. In: Cossu R, Stegman R, Christensen TH (eds) 7th International waste management and landfill symposium. Sant Margarita di Pula, pp 389-392

Bédard D (2005) Effet du fluage à long terme des sous-produits de désencrage dû à la perte de masse et son effet sur la compression et la conductivité hydraulique. M.Sc.A. Thesis, Université de Sherbrooke, $166 \mathrm{p}$

Berger J, Fornes LV, Ott C, Jager J, Wawra B, Zanke U (2005) Methane oxidation in a landfill cover with capillary barrier. Waste Manag 25(4 SPEC ISS):369-373

Bews BE, O'Kane MA, Wilson GW, Williams D, Currey N (1997) The design of a low flux cover system, including lysimeters, for acid generating waste rock in semi-arid environments. In: 4th International conference on acid 
mine drainage, Vancouver, 31 May-6 June, vol II, pp 747-762

Burnotte F, Lefebvre G, Cabral A, Audet C, Veilleux A (2000) Use of deinking residues for the final cover of a MSW landfill. In: 53rd Canadian geotechnical conference, Montreal, 15-18 Oct, vol 1, pp 585-591

Bussiere B, Aubertin M, Chapuis RP (2003) The behavior of inclined covers used as oxygen barriers. Can Geotech J 40(3):512-535

Bussière B, Aubertin M, Aachib M, Chapuis RP, Crespo JR (1995) Unsaturated flow modelling of covers for reactive tailings. In: Mitri $\mathrm{H}$ (ed) 3rd Canadian conference on computer applications in the mining industry (CAMI95), Montréal. 22-25 Oct, pp 853-862

Bussière B, Nicholson RV, Aubertin M, Benzaazoua M (1997) Evaluation of the effectiveness of covers built with desulfurized tailings for preventing acid mine drainage. In: 50th Canadian geotechnical conference of the Canadian Geotechnical Society, Ottawa, 20-22 Oct

Bussière B, Aubertin M, Morel-Seytoux HJ, Chapuis RP (1998) A laboratory investigation of slope influence on the behaviour of capillary barriers. In: 51th Canadian geotechnical conference, Edmonton, vol 12, pp 831836

Bussière B, Aubertin M, Julien M (2001) Couvertures avec effet de barrière capillaire pour limiter le drainage minier acide: aspects théoriques et pratiques. Vecteur Environ 34(3):38-50

Bussière B, Apithy S, Aubertin M, Chapuis RP (2003) Diversion capacity of sloping covers with capillary barrier effect. In: 56th Annual Canadian geotechnical conference, 4th joint IAH-CNC and CGS groundwater specialty conference \& 2003 NAGS conference, Winnipeg, p 8

Bussière B, Aubertin M, Zhan G (2007) Discussion: design of inclined covers with capillary barrier effect by S. E. Parent and A. Cabral. Geotech Geol Eng 25:673-678. doi: $10.1007 / \mathrm{s} 10706-007-9139-2$

Cabral A, Racine I, Burnotte F, Lefebvre G (2000) Diffusion of oxygen through a pulp and paper residue barrier. Can Geotech J 37(1):201-217

Cabral AR, Tremblay P, Lefebvre G (2004) Determination of the diffusion coefficient of oxygen for a cover system composed of pulp and paper residues. Geot Testing J 27(2):184-197

Cabral AR, El-Ghabi B, Parent S-É, Marineau L (2007) Design and performance of an experimental double capillary barrier cover placed in a municipal solid waste landfill. In: 11 th International waste management and landfill symposium. Sta. M. di Pula, 1-6 Oct

Cifuentes E, Aubertin M, Chapuis RP, Molson J, Bussière B (2006) Analyses of the water diversion length of inclined, layered soil covers. In: 59th Canadian geotechnical conference and the 7th Joint CGS/LAH-CNC groundwater specialty conference, sea to sky geotechnique, Vancouvert, 1-4 Oct, pp 1744-1749

Fredlund DG, Xing AQ (1994) Equations for the soil-water characteristic curve (Vol 31, Pg 521, 1994). Can Geotech J 31(6): 1026

Fredlund MD, Fredlund DG, Wilson GW (2000) An equation to represent grain-size distribution. Can Geotech J 37(4):817-827 
Gouvernement du Québec (2009) Règlement sur l'enfouissement et l'incinération des matières résiduelles

Hill DE, Parlang J-Y (1972) Wetting front instability in layered soils. Soil Sci Soc Am 36:697-702

Kamon M, Inazumi S, Takashi T, Inui T (2001) Waste sludge applicability and waste balance analysis of landfill cover system. In: Proceedings of the 1st Korea-Japan joint seminar on geoenvironmental engineering, Seoul, 6-7 Apr, pp 31-38

Kämpf M, Montenegro H (1997) On the performance of capillary barriers as landfill cover. Hydrol Earth Syst Sci 4:925-929

Kämpf M, Holfelder T, Montenegro H (1999) Designing capillary barriers. In: Christensen TH, Cossu R, Stegman R (eds) 7th International waste management and landfil symposium, St-Margarita di Pula. CISA, Environmental Sanitary Engineering Centre, pp 381-388

Kämpf M, Holfelder T, Montenegro H (2003) Identification and parameterization of flow processes in artificial capillary barriers. Water Resour Res 39(10):21-29

Khire MV, Benson CH, Bosscher PJ (2000) Capillary barriers: design variables and water balance. J Geotech Geoenviron Eng 126(8):695-708

Kisch M (1959) The theory of seepage from clay-blanketed reservoirs. Géotechnique 9-9-21

Lacroix Vachon B (2008) Les écoulements dans les milieux non saturés et leurs applications aux couvertures avec effet de barrière capillaire installées dans un site d'enfouissement sanitaire M.Sc.A. Thesis, Université de Sherbrooke, $138 \mathrm{p}$

Lacroix Vachon B, El-Ghabi B, Cabral AR (2007) Évaluation préliminaire de l'efficacité du recouvrement avec double effet de barrière capillaire installé au site de St-Tite-desCaps, Qc. In: 60e Conférence géotechnique canadienne, Ottawa, 21-24 Oct

Leij, FJ, Alves WJ, van Genuchten M (1996) The UNSODA unsaturated soil hydraulic database. EPA/600/R-96/095. EPA and US Sal. Lab. Riverside, CA

Maltby V, Eppstein K (1994) A Field-Scale study of the use of paper industry sludges as hydraulic barriers in landfil cover systems. In Daniel DE, Trautwein SJ (eds) Hydraulic conductivity and waste contaminant transport in soil ASTM STP 1142, Philadelphia. American Society for Testing and Materials, pp 546-558

Maqsoud A. Bussière B, Aubertin M (2004) Hysteresis effects on the water retention curve: a comparison between laboratory results and predictive models. In: 57th Canadian geotechnical conference and the 5th joint CGS-IAH conference, Quebec City. CGS, Vol. Session 3A, pp 8-15

Molson J, Aubertin M, Bussiere B, Benzaazoua M (2008) Geochemical transport modelling of drainage from experimental mine tailings cells covered by capillary barriers. Appl Geochem 23(1):1-24

Moo-Young HK, Zimmie TF (1996) Geotechnical properties of paper mill sludges for use in landfill covers. J Geotech Eng 122(9):768-775

Morel-Seytoux HJ (1994) Steady-state effectiveness of a capillary barrier on a sloping interface. In: Morel-Seytoux HJ (ed) 14th Hydrology days, Atherton, CA. Hydrology Days Publications, pp 335-346
Morel-Seytoux HJ (1995) Assessment of the performance of a capillary barrier. In: 2nd International conference on tailings \& mine waste, Fort Collins, Jan 1995. Balkema, pp 211-217

Morris CE, Stormont JC (1999) Parametric study of unsaturated drainage layers in a capillary barrier. J Geotech Geoenviron Eng 125(12):1057-1065

Mualem Y (1976) A new model for predicting the hydraulic conductivity of unsaturated porous media. Water Resour Res 12:513-522

Oldenburg CM, Pruess K (1993) On numerical modelling of capillary barriers. Water Resour Res 29(4):1045-1056

Panarotto CT, Cabral AR, Lefebvre G (2005) Biochemical evolution of a cellulose-rich by-product used as alternative cover material. J Env Eng Sci 4:123-138

Parent S-É, Cabral AR (2006) Design of inclined covers with capillary barrier effect. Geotech Geol Eng J 24:689-710

Parent SE, Cabral A, Gras G, Marinho F (2006) Design and installation of zero-tension lysimeters in an inclined cover. American Society of Civil Engineers, Carefree, pp 625-633

Quiroz JD, Simpson PT, Zimmio TF (2000) Evaluation of paper sludge landfill cover settlement. In Reston VA (ed) Proc. of session of Geo-Denver 2000. Geotechnical special publication no. 265, American Society of Civil Engineers, vol 10, pp 16-31

Robart G (1998) Étude de la perméabilité de la compressibilité des résidus de désencrage (Study of the permeability and compressibility of deinking residues). M.Sc.A., Université de Sherbrooke, Sherbrooke

Ross B (1990) Diversion capacity of capillary barriers. Water Resour Res 26(10):2625-2629

Shackelford CD, Chang C-K, Chiu T-F (1994) The capillary barrier effect in unsaturated flow through soil barriers. In: ISSMFE-CGS WDC (ed) Proceedings of the 1st international congress on environmental geotechnics, Edmonton, pp 789-793

Sowers GF (1973) Settlement of waste disposal fills. In: 8th International conference on soil mechanics and foundation engineering, Moscow, vol 2, pp 207-210

Steenhuis TS, Parlange JY, Kung KJS (1991) Comment on 'the diversion capacity of capillary barriers' by Benjamin Ross (paper 91WR01366). Water Resour Res 27(8):2155

Stormont JC (1995a) The performance of two capillary barriers during constant infiltration. Special geotechnical publication. Annu ASCE Conv 53:77-91

Stormont JC (1995b) The effect of constant anisotropy on capillary barrier performance. Water Resour Res 31:783-785

Stormont JC (1996) The effectiveness of two capillary barriers on a 10\% slope. Geotech Geol Eng J 14:243-267

Stormont JC, Anderson CE (1999) Capillary barrier effect from underlying coarser soil layer. J Geotech Geoenviron Eng $125(8): 641-648$

Stormont JC, Morris CE, Finley RE (1996) Capillary barriers for covering mine wastes. In: Tailings and mine waste, Fort Collins, pp 201-210

Teixeira CE (2001) Evolution biochimique des résidus de désencrage dans un contexte de valorisation comme barrière de recouvrement (Biochemical evolution of deinking 
residues in the context of its reuse as cover material). Ph.D. Thesis Thesis, Université de Sherbrooke, 209 p

Terzaghi K, Peck RB (1967) Soil mechanics in engineering practice. 2 e edition, John Wiley \& Sons Inc, New York

Tidwell V, Glass R, Chocas C, Barker G, Orear L (2003) Visualization experiment to investigate capillary barrier performance in the context of a yucca mountain emplacement drift. J Contam Hydrol 62(3):287-301

USBR (1974) Design of small canal structures. Bureau of Reclamation, Denver

van Genuchten MT (1980) A closed-form equation for predicting the hydraulic conductivity of unsaturated soils. Soil Sci Soc Am J 44:892-898

van Genuchten MT, Leij FJ, Yates SR Z(1991) The RETC code for quantifying the hydraulic functions of unsaturated soils, Report EPA/600/2-91/065, US Department of Agriculture, Agriculture Research Service

von Der Hude N, Huppert F (1998) Capillary barriers for the surface sealings of landfills. Water-Rock Interaction, pp 1005-1008

von Der Hude N, Melchior S, Mōckel S (1999) Construction of a capillary barrier in the cover of the Breinermoor landfill. In: Christensen TH, Cossu R, Stegman R (eds) 7th International waste management and landfill symposium, Sta Margarita di Pula. CISA, pp 393-402

Wawra B, Holfelder T (2003) Development of a landfill cover with capillary barrier for methane oxidation-the capillary barrier as gas distribution layer. In: 9th International waste management and landfill symposium, Italy, 6-10 Oct

Webb SW (1997) Generalization of Ross tilted capillary barrier diversion formula for different two-phase characteristic curves. Water Resour Res 33(8):1855-1859

Yanful EK, Mousavi M, De Souza LP (2006) A numerical study of soil cover performance. J Environ Manag $81: 72-92$

Yang H, Rahardjo H, Leong EC, Fredlund DG (2004) A study of infiltration on three sand capillary barriers. Can Geotech J 41(4):629-643

Zhan G, Mayer A, McMullen J, Aubertin M (2001) Slope effect study on the capillary cover design for a spent leach pad. In: 8th International conference tailings and Mine Waste'01, Colorado State University, Forth Collins, Balkema, Rotterdam, The Netherlands, pp 179-187

Zhan G, Schafer W, Milczarek M, Myers K, Giraudo J, Espell R (2006) The evolution of evapotranspiration cover system at Barrick Goldstrike Mines. In: 7th International conference on acid rock drainage, ICARD 06, pp 2585-2603

Zhang Q, Werner A, Aviyanto R, Hutson J (2009) Influence of soil moisture hysteresis on the functioning of capillary barriers. Hydrol Process 23:1369-1375 